\title{
The effect of using L1 in EFL teaching on secondary school students' vocabulary achievement
}

\author{
Siti Fatimah ${ }^{1}$, Susilo Susilo ${ }^{2}$, Hasby Sjamsir ${ }^{3}$ \\ Faculty of Education and Teacher, Mulawarman University, Indonesia \\ olisusunmul@gmail.com
}

\begin{abstract}
This study aims at answering three research questions: 1) how is the vocabulary achievement of the SMPN 27 Samarinda eight grade students who were taught English subject (L2) by using both L1? and 2) is there any significant different between students' vocabulary achievement of the eight grade students at SMPN 27 Samarinda before and after being taught English subject (L2) by using L1? This is an experimental study using one-group pre-test post-test design. the population are all eight grade students at SMPN 27 Samarinda (seven parallel classes). Based on the list of the mean scores of each class in English subject (see table 2), then class VIII-E is chosen as the sample. There are two instruments used in this study, i.e. test and questionnaire. To test the hypotheses, the researchers used inferential statistics, i.e. paired sample t-test. It was used as the test of significance between students' scores before they experienced the treatment and after they received the treatment. This study finds out that there is a significant difference in the score of pretest $(M=62.17, S D=13.43)$ and posttest $(M=73, S D$ $=13.43$ ) conditions; $t(29)=\mathbf{- 9 . 2 0}, p<.001$, which implies the use of bahasa Indonesia (L1) in teaching English subject to the eight grade students of SMPN 27 Samarinda does have effect on their vocabulary achievement. From above facts, it can be concluded that the using L1 in EFL context can increase the vocabulary achievement.
\end{abstract}

Keywords-EFL teaching, Vocabulary achievement, secondary school, the use of $L 1$

\section{INTRODUCTION}

The status of English as a foreign language in Indonesia makes English learners awkward to speak at anytime; as a consequence, they have to learn it harder in the classroom. Even though nowadays internationally in some fields such as: politics, diplomacy, international trade and industry, commerce, science and technology, education, the media, information technology, or popular culture, all almost all information is addressed in English as the impact of English being used as an international lingua franca [10, 13], in Indonesia, the importance of using the national language, i.e. Bahasa Indonesia, still gets the position of highest priority. It is not doubt that although in English class, Bahasa Indonesia is still important to use. Moreover, the use of L1 in teaching L2 is not something wrong at all. Some research findings reveals the advantages of using L1 in teaching L2; for instance, the use of L1 was useful for teaching and learning culture-related issues [2], using learners' mother tongue (L1) to teach English as a foreign language in Laos improved the better memory of new vocabulary items [8], majority teachers and students believe that the mother tongue must be presented in the classroom [17], using L1 can achieve better vocabulary achievement on students [20], and there is no empirical evidence that L1 can hinder the language role in the EFL classroom [7].

Learning English in through a real task is now getting more important. Therefore, in Indonesia, since the use of English as a lingua franca is not possible, the L2 classroom atmosphere should be very enjoyable in order that feeling in a real learning is not haunted the learners, which in turn increases their motivation to acquire the L2 outside class as the ways to maximize utilizing opportunities of L2 exposure [23]. In addition, [3] points out that today even in the status of English as an international language, Indonesian teens prefer to speak English only for the high prestige and being impressive. In the meantime, adults think that English is more crucial than their own language. This study aims at answering three research questions: 1) how is the vocabulary achievement of the SMPN 27 Samarinda eight grade students who were taught English subject (L2) by using both L1? and 2) is there any significant different between students' vocabulary achievement of the eight grade students at SMPN 27 Samarinda before and after being taught English subject (L2) by using L1?

\section{THEORETICAL REVIEWS}

\section{A. The Use of L1 in EFL Context}

Many language teaching professionals argue the use of L1 in L2 classroom is important. Mattioli in Bouangeune (2009) states there are several reasons why L1 should be used as a tool in language classroom [8]: 1) it is more natural to use L1 with others who have the same $\mathrm{L} 1$; 2) $t$ is easier and effective to use the L1; 3) for shy students, L1 can be a source of embarrassment when they felt that they are not good in L2; 4) L1 may facilitate classroom activities, particularly for low proficiency students; and 5) L1 can provide a foundation to understand L2 structure. That is why the L1 use in L2 classroom is still needed. Furthermore, [26] ensures that teachers should use as much L2 as possibble when the students only have a short time to learn English in the class on daily basis. As it is in EFL Indonesian classroom where students only get 270 minutes in a week, such concept is appropprite. There are some strategies to use L1 in the classroom, among others are:

a. Change the character names or brands in the text to well-known names in Indonesia. From [28], one of her research subject changes the character names in text from US Presidents to Indonesian Presidents. Also, 
some well-known brands can be used such Mie Sedap, Masako or Gery Saluut.

b. Give listening aids using by teacher's own English accent. By listening on how Indonesian speaks English, students will get to know the real English used in their country. Also, British or American English do not so matter.

c. Bring teacher's own cultural aspects. In EFL, Indonesian culture is also being important as English culture.

d. [24] suggests teachers to use L1 frequently in beginning and intermediate classes to: Give instruction, Explain meanings of words, Explain complex ideas, Explain complex grammar points

e. [4] reviews the functions for teachers used L1 in: Explaining the rules of grammar and word meanings, Discussing cultural ideas, Giving feedback, Pointing out the differences between the structure of each language

It is apparent that teaching English in EFL context using L1 should be limited as it should be applied in such ways.

\section{B. The L2 Use in EFL Context}

In Indonesian classroom where students learn English while share the same first language, the use of L2 should be considered. Teachers need to encourage the students to use the L2 as much as possible [21]. In addition, the L1 can be used as a teaching tool alongside the L2 but not substituting L2 together (Cook in [5]). Further, [1] provided some of the ways of dealing with encouraging L2 use as follows.

a. Choose suitable tasks that are within the learners' proficiency.

b. Prepare the students for tasks by pre-teaching the language items and skills.

c. Use staged and graded tasks that bring students up to the level required.

d. Get learners to pretend to be English speakers.

e. Apply retelling activities, strip stories, completion activities, and role plays which require the use of $\mathrm{L} 2$.

f. Repeat tasks to make them easier.

g. Inform the students of learning goals in each task so they can see how using L2 will help them to achieve the learning goal.

h. Discuss with the students about the value of using L2 in classroom.

i. Discuss the reasons why the students avoid using the L2 and give them the solutions.

j. Set up a monitoring system to remind the students to use L2.

k. Use interesting tasks where the students get excited to work on it.

1. As the students learning the L2 so teachers should not push away the purpose of L2 itself.

\section{Advantages and Disadvantages of Using L1}

The use of Bahasa Indonesia as L1 in EFL context also has both advantages and disadvantages. According to [9], the use of L1 increases students' confidence in expressing ideas. Students simply can say what they want to say by using L1 in learning L2 activities. In addition, the proper application of L1 can effectively facilitate the memorization of new words because it gives the students a sense of the meaning of word [15]. Despite the advantages of using L1, [16] says that the use of L1 is a barrier to learning L2. Because when the students are supposed to learn English but the interfering of another language obstruct them. Moreover, in the earlier Atkinson in [14] stressed some following problems when the use of L1 is applied, i.e.: 1) The teacher and students begin to feel that they have not really understood any item of L2 until it has been translated; 2) The teacher and students fail to observe the distinctions between equivalence of form, semantic equivalence, and pragmatic features of L2;3) Students speak to the teacher in L1 as a matter of course even when they quite capable of expressing what they mean in L2; and 4) Students fail to realize that during many activities in the classroom is essential that they use only L2.

Apparently, it can be said that implementing L1 in teaching English is not a wrong decision. But still, the teacher should consider the weak forms of it. Moreover, the overuse of using L1 will be not good enough.

\section{Definition of Vocabulary}

Vocabulary is a list of words, usually in alphabetical order and with explanations of their meanings [27]. While [25] states that vocabulary is a very important part of learning a language especially English. It is needed to express the meaning of words in productive skill (speaking and writing) and receptive skill (listening and reading). The role of vocabulary cannot be ignored in learning English in order to acquire the four language skills. Also, vocabulary is a list of words with their meanings, especially in a book for learning a foreign language [22]. It can be concluded that a vocabulary is a group of words which becomes a basic thing in language and needed to be mastered by the language learners in supporting an effective communication and expressing an idea in the form of oral or written.

\section{E. Types of Vocabulary}

In vocabulary types, one classification involves the two terms of vocabulary [21] Receptive vocabulary which is known as the words that are being able to recognize when it is heard or when it is seen and having an expectation of what grammatical pattern of the word occurs, and 2) Productive vocabulary that is known as the words that are being to pronounce, how to write and to spell it, how to use it in a grammatical pattern along with the word in usually collocate with it. In addition, there are two kinds of vocabulary according to [11], i.e.1) Active vocabulary that is used in oral and written expression by students. Also, students understand the words well enough and they use the words effectively in both speaking and writing, and 2) Passive vocabulary that deals with words the students will recognize understand in a context that helps them recall the meaning of word. Also, students usually apply this kind of vocabulary in listening and reading materials. Obviously, it is considered to specify what kind of vocabulary that will be used in such materials at teaching and learning process. Moreover, 
[12] states that word can be classified based on their functional categories and it is called part of speech. It concludes nouns, verbs, adjectives, adverbs, pronouns, conjunctions and prepositions. In this research, it will be focused on nouns, verbs, and adjectives.

Nouns

[12] claims that all parts of speech have a semantic core that is language-independent. The most core like nouns or first order nouns are names of people and physical objects, and entities that exist in time and space. While second-order nouns are observable things which take place and time. Therefore, these would include nouns of states (e.g., sleep), process (e.g. weaving) and events (e.g., a crash). The third-order are prepositions that are truly abstract with no relation to time and space. The more cores like the nouns are, the easier it should be learned. In short, nouns is the name of a person, place, thing, idea or quality.

Verbs

Verbs are words that donate action. [12] states that those verbs are placed into four classes: activities, accomplishments, achievements, and states.

\section{Adjectives}

Adjectives are used to highlight qualities or attributes. Certain adjectives are typically used to describe particular nouns. This research will focus on major classes which are considered to be taught for learners because they are appropriate for the material on the syllabus.

\section{F. The Aspects of Vocabulary}

In learning vocabulary, there are some aspects that can be learned by the learners. According to Lado in Mardianawati (2012), the aspects of vocabulary that can be learnt by the students as follows.

a. The meaning of the word should be known in learning a foreign language. Knowing the meaning of the words will make students easier to communicate on written or oral.

b. Also, spelling is very important. It can tighten the connection between sound and letters. Spelling and listening also have a common factor and proficiency with the language.

c. Able to pronounced the words can make the students communicate with others without hindrance. Thus, the teacher needs to guide students to pronounce correctly.

d. Word-classes are important feature in semantic analysis. The examples of word class are; nouns, verbs, adverb, adjectives, and preposition. The classification of the word of a language depends on the function in communication. Nouns can occur in certain places in a sentence and serve certain functions. Verbs also occur in certain places and have special function. Thus, wordclass membership is an important lexical feature.

e. Word use is how a word, phase, or concept is used in a language. It may also involve grammar and thus become the subject of profound analysis.
In addition, there are several aspects of lexis that need to be taken part in teaching vocabulary as stated by [19].

a. Boundaries are knowing not only what lexis to but also how it separates from words related meaning, as a cup, mug, bowl.

b. Polysemy is differentiating between the various meaning of a single word from several and closely related meaning, such: head of a person, head of a pin, and head of an organization.

c. Homonymy is differentiating between the various meaning of a single word from some meanings that is not related, as a file used to put papers in or a file in a tool.

d. Homophony is understanding words that have the same pronunciation but different spellings and meanings, such: flour and flower.

e. Synonymy is distinguishing between the different meaning that synonymous words have, as to extend, to increase and to expand.

f. Affective meaning is differentiating between the attitudinal and emotional factors (denotation and connotation) which depend on how speakers' attitude or the sociocultural situations.

g. Style register is distinguishing between different level of formality, the effect context and topics in a dialect.

h. Translation is being aware of the several differences and similarities between the native and the foreign language.

i. Chunks of language are like in multiword verbs, idioms, strong and weak collocation, and also lexical phrases.

j. The grammar of vocabulary is learning the rules that make students to build up different forms of a single word or even different words from that word, such: sleep, slept, sleeping, able, unable, disability.

k. Pronunciation is being able to recognize and reproduce items in speech.

Apparently, it can be concluded that all vocabulary aspects must be known and understood by the teacher in teaching vocabulary in the class in order the students know the aspects well.

\section{RESEARCH METHODOLOGY}

This is an experimental study using one-group pre-test post-test design. The independent variable is teaching using L1 in English classroom, while the dependent variable is students' vocabulary achievement, Table I.

\section{TABLE I. DESIGN OF THE STUDY}

\begin{tabular}{|l|l|l|}
\hline Pre-test & Independent Variable & Post-test \\
\hline Y1 & $\mathrm{X}$ & Y2 \\
\hline
\end{tabular}

\section{A. Population and Sample}

In this study, the population are all eight grade students at SMPN 27 Samarinda. The reasons of choosing the school since it is a public school where all students have different language 
acquisition and learning language abilities. The total population is 210 students (see Table II).

\section{TABLE II. TOTAL OF STUDENT}

\begin{tabular}{|l|l|}
\hline Name of the parallel class & Number of Students \\
\hline VIII-A & 31 \\
\hline VIII-B & 29 \\
\hline VIII-C & 30 \\
\hline VIII-D & 30 \\
\hline VIII-E & 30 \\
\hline VIII-F & 29 \\
\hline VIII-G & 31 \\
\hline Total & 210 \\
\hline
\end{tabular}

Of the seven parallel classes, using cluster sampling technique, all classes are identified by having their mean scores of English subject. Based on the list of the mean scores of each class in English subject (see Table III), then class VIII-E is chosen as the sample.

TABLE III. STUdENTS'MEAN SCORES IN ENGLISH SUBJECT

\begin{tabular}{|l|l|}
\hline Class & Mean Scores \\
\hline VIII-A & 73.80 \\
\hline VIII-B & 74.00 \\
\hline VIII-C & 71.00 \\
\hline VIII-D & 70.34 \\
\hline VIII-E & 68.04 \\
\hline VIII-F & 69.87 \\
\hline VIII-G & 72.14 \\
\hline
\end{tabular}

\section{B. Instruments}

There are two instruments used in this study, i.e. test and questionnaire. The test is vocabulary test, which is a researcher-made test consisting of 20 items in the form of multiple choice. The validity and reliability of the test has been firstly measured through a try-out. The questionnaire was adapted from "California State University Channel Islands of Student Opinion of Teaching Survey" (2014) and "Use of Other Languages in English Language Teaching at Tertiary Level: A Case Study on Bangladesh" (Mirza et al., 2012). Originally, the questionnaire comprised of 14 items and 6 items. Then, the researchers only took 3 items from University Channel Islands and 5 items from Mirza et al. Thus, the questionnaire used in the study consists of 8 questions which are divided into self-ratings (3 numbers) and teaching opinion ( 5 numbers). In addition, the questionnaire is in form of closeended with Likert scale. For the sake of avoiding misinterpretation for the respondents, the questionnaire was translated into Bahasa Indonesia. The translated questionnaire has been tried out by reading aloud in front of students and asking whether it is clear or beyond their understanding. Furthermore, to see the result of the treatment, observation checklist was used in a quantitative way. This instrument was made to see the frequency of using Bahasa Indonesia. This observation checklist consists of 6 teacher activities in the classroom. The kind of teacher activities was developed from Doyle (1986).

\section{Data Collection Technique}

In collecting the data, the researchers employed the following procedures:

1. Giving try-out in another class neither experimental class to check the degree of difficulty, discriminating power, validity, and reliability of the test.

2. Analyzing the result of try-out and selecting good items.

3. Giving pre-test to experimental group of the eight grade students of SMP Negeri 27 Samarinda.

4. Collecting the scores to find pre-test result.

5. Giving the treatment by teaching English using Bahasa Indonesia to experimental group for 6 meetings.

6. During the treatment, observation checklist is fulfilled.

7. Giving post-test to experimental group of the eight grade students of SMP Negeri 27 Samarinda.

8. Giving questionnaire to see the students' opinion toward the using of Bahasa Indonesia in English classroom.

9. Collecting the scores to find the post-test result.

\section{Data Analysis Technique}

To test the hypotheses, the researchers used inferential statistics, i.e. paired sample t-test. It was used as the test of significance between students' scores before they experienced the treatment and after they received the treatment. Prior to the t-test, normality test and homogeneity test were conducted. SPSS program was used to provide descriptive, inferential statistics and graphical presentations.

\section{E. Internal validity}

To avoid the threats of internal validity, in this study, more than one observer made observations in the process of giving treatments. It was done in the purpose of standardizing the treatment condition. In addition, the administration of the tests was done tightly.

\section{RESULT}

\section{A. The Result of Pre-Test}

The pre-test is done for collecting the data to answer research question 1, which aims at know student's vocabulary achievement before treatment. The result of pre-test shows that the scores of the students before treatment lies in various intervals. There are four students $(13 \%)$ get in the excellent classification; seven students $(23 \%)$ are included in the good classification; and eight students $(27 \%)$ are in fair classification; six students $(20 \%)$ are labeled in the poor classification; five students (17\%) get fail classification, (see Table IV). 
TABle IV. The Percentage of Pre-test Result

\begin{tabular}{|l|l|l|l|l|}
\hline $\begin{array}{l}\text { Interval } \\
\text { Scores }\end{array}$ & Qualification & Classification & Frequency & Percentage \\
\hline $80-100$ & A & Excellent & 4 & $13 \%$ \\
\hline $70-79$ & B & Good & 7 & $23 \%$ \\
\hline $60-69$ & C & Fair & 8 & $27 \%$ \\
\hline $50-59$ & D & Poor & 6 & $20 \%$ \\
\hline $0-49$ & E & Fail & 5 & $17 \%$ \\
\hline
\end{tabular}

\section{B. The Result of Posttest}

The post-test is done for collecting the data to answer research question 1, which aims at know student's vocabulary achievement after treatment, i.e. teaching English subject by using Bahasa Indonesia. The result of post-test reveals that there are 13 students $(43 \%)$ get excellent classification; six students (20\%) obtain good classification: eight students (27\%) are in the fair classification; two students $(7 \%)$ get poor classification; only one student (3\%) fail classification (see Table V).

TABle V. The Percentage of Post-test Result

\begin{tabular}{|l|l|l|l|l|}
\hline $\begin{array}{l}\text { Interval } \\
\text { Scores }\end{array}$ & Qualification & Classification & Frequency & Percentage \\
\hline $80-100$ & A & Excellent & 13 & $43 \%$ \\
\hline $70-79$ & B & Good & 6 & $20 \%$ \\
\hline $60-69$ & C & Fair & 8 & $27 \%$ \\
\hline $50-59$ & D & Poor & 2 & $7 \%$ \\
\hline $0-49$ & E & Fail & 1 & $3 \%$ \\
\hline
\end{tabular}

The comparison of the results of pre-test and post-test that the students did can be seen in the chart as described in Fig. 1. The percentage of those who get excellent classification in the post-test is drastically increased. Meanwhile, for the poor and fail classification, the number is drastically decreased. These all mean that there is an increasing achievement on the students' vocabulary.

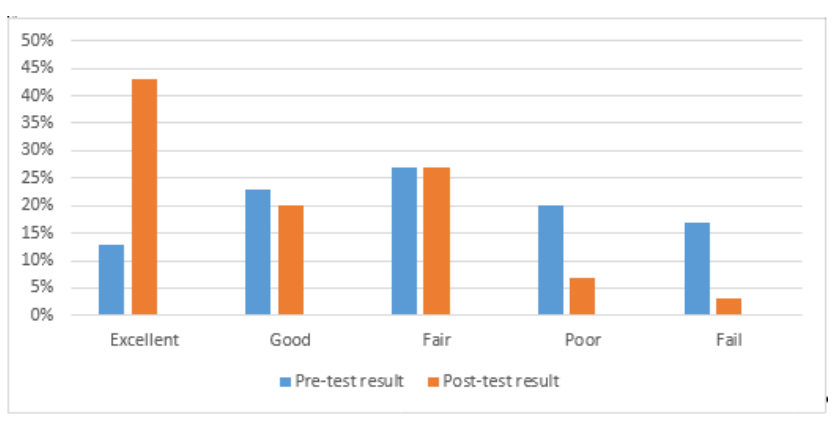

Fig. 1. The comparison of the results of pre-test and post-test

\section{RESEARCH FINDINGS AND DISCUSSION}

This study finds out that there is a significant difference in the score of pretest $(M=62.17, S D=13.43)$ and posttest $(M=$ $73, S D=13.43)$ conditions; $t(29)=-9.20, p<.001$, which implies the use of bahasa Indonesia (L1) in teaching English subject to the eight grade students of SMPN 27 Samarinda does have effect on their vocabulary achievement. From above facts, it can be concluded that the using L1 in EFL context can increase the vocabulary achievement. This finding is in line with what Tang's (2002) finding revealing that limited and thoughtful use of mother tongue in the English classroom does not reduce students' experience to English, but rather can assist in the teaching and learning processes. However, in any cases, Agustin (2015) reminds that although using L1 is useful but the continuous use of L1 would be dangerous. Furthermore, Liu (2008) states L1 use in teaching vocabulary gives an easier and more efficient way to describe the core meaning of words.

The context of using L1 in EFL teaching seems not to be sinful. The L1 is used but not all the time when teaching; however, L2 teachers tend to use their L1 as proportional as possible since they believe that using L1 in teaching L2 is not an obstacle. As it is found in the study, the observation checklist shows that bahasa Indonesia (L1) is used on $42 \%$ of speaking time in classroom. This fact is also seen in several studies such Alrabah et al. (2016) showing that in many EFL classrooms from different language backgrounds, the teacher used L1 for more than $40 \%$ of actual class speaking time. However, the use of English language itself gets equal portion. Liu (2008) confirms that the use of L1 is not the barrier but rather be a facilitator. In addition, this study suggests that what most teachers use Bahasa Indonesia is as to explain the material, translate the difficult vocabularies and give feedback. It is in line with what is stated by Lado et all in Nation (2003) that the L1 translation in teaching new L2 words is the most effective way in using L1 in L2 classroom.

\section{CONCLUSION}

There are two conclusions that the result of the study draws. Firstly, the percentage of the students' vocabulary achievement for those who get excellent classification in the post-test is drastically increased. Meanwhile, for the poor and fail classification, the number is drastically decreased. This suggests that there is an increasing vocabulary achievement of the students who were taught English subject by using L1. Secondly, there is a significant difference in the score of pretest $(M=62.17, S D=13.43)$ and posttest $(M=73, S D=13.43)$ conditions; $t(29)=-9.20, p<.001$. This suggests that the use of bahasa Indonesia (L1) in teaching English subject to the eight grade students of SMPN 27 Samarinda does have effect on their vocabulary achievement.

\section{REFERENCES}

[1] Afzal, S. (2013). Using of the First Language in English Classroom as a Way of Scaffolding for Both the Students and Teachers to Learn and Teach English. International Research Journal of Applied and Basic Science, 4 (7): 1846-1854.

[2] Agustin, D. T., \& Mujiyanto, J. (2015). The Use of Bahasa Indonesia (L1) In The Intensive English (L2) Classroom. English Education Journal, 5 (1):...

[3] Agustina, D. (2015). Bahasa Inggris Tak Seharusnya ‘Gantikan’ Bahasa Indonesia. CNN Indonesia.

[4] Al-Jadidi, H. S. S. (2009). Teaching English as a Foreign Language in Oman: an Exploration of English Language Teaching Pedagogy in 
Tertiary Education. unpublished Doctoral dissertation, Victoria University.

[5] Alrabah, S., Wu, S. H., Alotaibi, A. M., \& Aldaihani, H. A. (2016). English Teachers' Use of Learners' L1 (Arabic) in College Classrooms in Kuwait. English Language Teaching, 9(1), 1-11.

[6] Arikunto, S. (2002). Prosedur Suatu Penelitian: Pendekatan Praktek. Edisi Revisi. Kelima. Jakarta: Rineka Cipta.

[7] Bhooth, A., Azman, H., and Ismail, K. (2013). The Role of the L1 as a Scaffolding Tool in the EFL Reading Classroom. Procedia-Social and Behavioral Sciences, 118: 76-84

[8] Bouangeune, S. (2009). Using L1 in Teaching Vocabulary to Low English Proficiency Level Students: A Case Study at the National University of Laos. English Language Teaching, 2 (3): 186-193.

[9] Cook, V. (2001). Using the first language in the classroom. Canadian Modern Language Review, 57(3), 402-423.

[10] Crysal, D. (2003). English as a global language. Cambridge: Cambridge University Press.

[11] Harmer, J. (1991). The practice of English language teaching. London/New York.

[12] Hatch, E., \& Brown, C. (1995). Vocabulary, Semantics, and Language Education. Cambridge University Press, 40 West 20th Street, New York, NY.

[13] Jenkins, J. (2003). World Englishes: A Resource Book for Students. Routledge English Language Introductions Series. London and New York: Routledge.

[14] Kavari, K. E. (2014) To Use or Not To Use Mother Tongue in ELT Classrooms, That is the Question. A Journal of Multidisciplianary Research, 3(6): 206-212

[15] Liu, J. (2008). L1 use in L2 vocabulary learning: Facilitator or barrier. International Education Studies, 1 (2): 65 -..

[16] Mahadeo, S. K. (2006). English Language Teaching in Mauritius. The International Journal of Language, Society and Culture. ...

[17] Manara, C. (2007). The Use of L1 Support: Teachers' and Students' Opinions and Practices in an Indonesian Context. The Journal of Asia TEFL, 4 (1): 145-178.
[18] Mardianawati, D. (2012). Penerapan Model Pembelajaran Berbasis Masalah pada Materi Energi Gerak untuk Meningkatkan Kreativitas Siswa Kelas III Madrasah Ibtidaiyah AL Marfuah Cihuni. Bandung: Universitas Pendidikan Indonesia.

[19] Munir, F. (2016). The Effectiveness of Teaching Vocabulary by Using Cartoon Film toward Vocabulary Mastery of EFL Students. Journal of English Language Teaching and Linguistics, 1(1). Retrieved from http://www. jeltl.org/

[20] Nation, I. S. P. (1990). Teaching and Learning Vocabulary. New York: Newburny House.

[21] Nation, I. S. P. (2001). Learning Vocabulary in Another Language. Cambridge: Cambridge University Press.

[22] Richard, J.C., \& Renandya, W.A. (2002). Methodology in Language Teaching: An Anthology of Current Practice. USA: Cambridge University Press.

[23] Susilo, S. (2016). Of leraning beyond the class: a survey on millennial generations of Indonesian pre-service teachers. Asian EFL Journal. 6: 05-33.

[24] Tang, J. (2002, January). Using L1 in the English classroom. In English Teaching Forum 40(1): 36-43

[25] Tumanggor, L. Y. (2013). Improving Students Achievement in Vocabulary Through Lustering Technique. Register Journal of English Language Teaching of FBS-Unimed, 2 (2):...

[26] Turnbull, M. (2001). There is a Role for the L1 in Second and Foreign Language Teaching, But.... Canadian Modern Language Review,57, 531-540.

[27] Wu, L. (2009). Incidental English Vocabulary Studying in L2 Learning. Unpublished MA Thesis. Kristianstad.

[28] Zacharias, N.T. (2014). Integrating EIL Pedagogy in a Pre-service Teacher Education Program. TEFLIN Journal, 25(2): 